\title{
Isotopic Characterization of HALEU from EBR-II Driver Fuel Processing
}

\author{
DeeEarl Vaden
}

November 2018

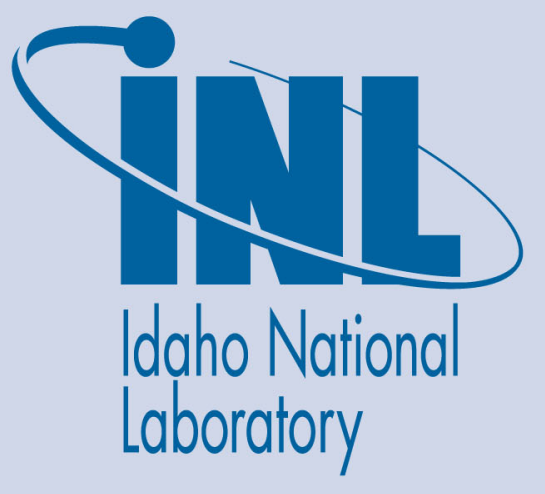

The INL is a U.S. Department of Energy National Laboratory operated by Battelle Energy Alliance 


\title{
Isotopic Characterization of HALEU from EBR-II Driver Fuel Processing
}

\author{
DeeEarl Vaden
}

November 2018

Idaho National Laboratory Idaho Falls, Idaho 83415

http://www.inl.gov

Prepared for the

U.S. Department of Energy

Under DOE Idaho Operations Office

Contract DE-AC07-05ID14517 
Rev. 05

Title: $\quad$ Isotopic Characterization of HALEU from EBR-II Driver Fuel Processing

TEV No.: 3537 Rev. No.: 0 Project No: 31059

Date: $10 / 17 / 2018$

\begin{tabular}{|c|c|c|}
\hline $\begin{array}{l}\text { Does this TEV involve a } \\
\text { 1. Safety SSC? }\end{array}$ & No & \multirow{6}{*}{$\begin{array}{c}\text { Professional Engineer's Stamp } \\
\text { N/A }\end{array}$} \\
\hline $\begin{array}{l}2 \text { Safety SSC Determination } \\
\text { Document ID }\end{array}$ & N/A & \\
\hline 3. Engineering Job (EJ) No. & $\mathrm{N} / \mathrm{A}$ & \\
\hline 4. SSC ID & N/A & \\
\hline 5. Building & 765 & \\
\hline 6. Site Area & MFC & \\
\hline
\end{tabular}

7. Introduction:

The purpose of this technical evaluation is to provide the isotopic characteristics of the High Assay Low Enriched Uranium (HALEU) product recovered during the used nuclear fuel treatment operations occurring at Idaho National Laboratory.

8. N/A

9. Conclusions/Recommendations:

To provide sufficient information to perform an isotopic characterization of HALEU produced at Idaho National Laboratory:

- The analytical results of casting furnace pin samples provide sufficient information of the measured nuclides.

- Isotopic distributions based on ORIGEN calculations coupled with the analytical results provide the characterization for the non-measured nuclides. 
TEM-10300-1

$12 / 19 / 2017$

TECHNICAL EVALUATION

Page 2 of 6

Rev. 05

Title: $\quad$ Isotopic Characterization of HALEU from EBR-II Driver Fuel Processing

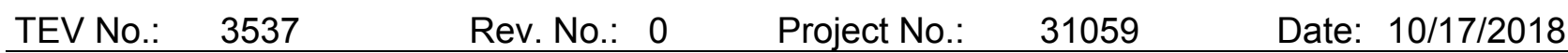

\section{CONTENTS}

PROJECT ROLES AND RESPONSIBILITIES .................................................................

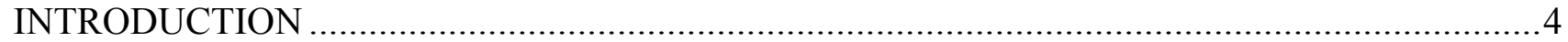

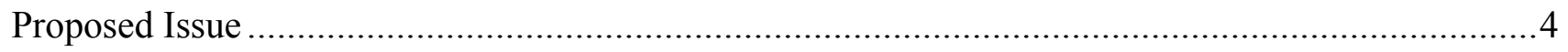

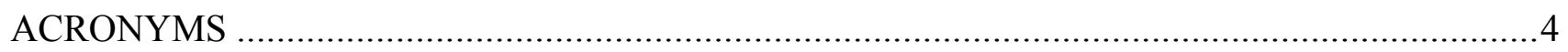

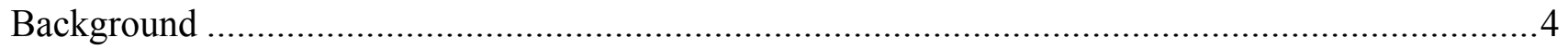

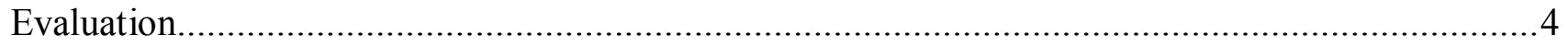

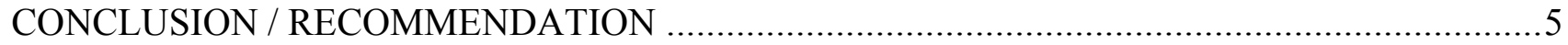

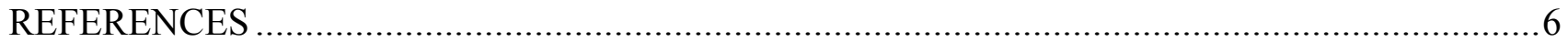

\section{APPENDIXES}

Appendix A - Engineering Inputs

Appendix B - HALEU Assay

Appendix C - Measured Chemical and Isotopic Composition of Six FCF Uranium Product Casting Batches $(202 \mathrm{~kg})$ 
Rev. 05

Title: $\quad$ Isotopic Characterization of HALEU from EBR-II Driver Fuel Processing

TEV No.: $\quad 3537$

Rev. No.: $0 \quad$ Project No.: 31059

Date: $10 / 17 / 2018$

\section{PROJECT ROLES AND RESPONSIBILITIES}

\begin{tabular}{|c|c|c|c|}
\hline Project Role & Name (Typed) & Organization & Pages covered (if applicable) \\
\hline Performer & Dee Earl Vaden & $\mathrm{C} 420$ & \\
\hline Checker $^{\mathrm{a}}$ & Brian R. Westphal & $\mathrm{C} 420$ & \\
\hline Independent Reviewer ${ }^{\mathrm{b}}$ & JC Price & $\mathrm{U} 710$ & \\
\hline CUI Reviewer ${ }^{\mathrm{c}}$ & N/A & & \\
\hline Manager $^{\mathrm{d}}$ & Doug Crawford & U000 & \\
\hline Requestor $^{\mathrm{e}}$ & Michael N. Patterson & $\mathrm{U} 600$ & \\
\hline Nuclear Safety ${ }^{\mathrm{e}}$ & $\mathrm{N} / \mathrm{A}$ & & \\
\hline Document Owner ${ }^{\mathrm{e}}$ & Michael N. Patterson & U600 & \\
\hline Responsibilities & & & \\
\hline
\end{tabular}
a. Confirmation of completeness, mathematical accuracy, and correctness of data and appropriateness of assumptions.
b. Concurrence of method or approach. See definition, LWP-10106.
c. Concurrence with the document's markings in accordance with LWP-11202.
d. Concurrence of procedure compliance. Concurrence with method/approach and conclusion.
e. Concurrence with the document's assumptions and input information. See definition of Acceptance, LWP-10300.

NOTE: Delete or mark "N/A" for project roles not engaged. Include ALL personnel and their roles listed above in the eCR system. The list of the roles above is not all inclusive. If needed, the list can be extended or reduced. 
Rev. 05

Title: $\quad$ Isotopic Characterization of HALEU from EBR-II Driver Fuel Processing

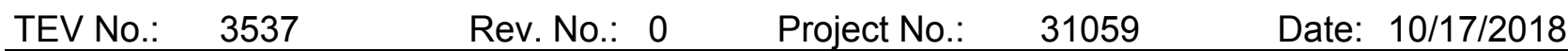

\section{INTRODUCTION}

\section{Proposed Issue}

To assess the feasibility of reusing High Assay Low Enriched Uranium (HALEU) recovered from the treatment of irradiated EBR-II fuel, an environmental assessment requires an isotopic characterization of the uranium product from the process deployed in the Fuel Conditioning Facility (FCF) at Idaho National Laboratory (INL). A bestavailable characterization is derived through a combination of measured values obtained through chemical and isotopic analysis and calculated values determined through the use of process modeling software and related programs.

\section{ACRONYMS}

$\begin{array}{ll}\text { CFBF } & \text { Casting Furnace Binary Fuel } \\ \text { EBR-II } & \text { Experimental Breeder Reactor II } \\ \text { FCF } & \text { Fuel Conditioning Facility } \\ \text { HALEU } & \text { High Assay Low Enriched Uranium (HALEU) } \\ \text { INL } & \text { Idaho National Laboratory } \\ \text { MTG } & \text { Mass Tracking System } \\ \text { ORIGEN } & \text { Oak Ridge Isotope Generator } \\ \text { PADB } & \text { Physics Analysis Database }\end{array}$

\section{Background}

As part of past and ongoing operations, fuel elements irradiated in EBR-II undergo processing via the Electrometallurgical Treatment (EMT) system which resides in FCF. Under this process, the metallic uranium used in the original construction of the element is separated from the bond sodium and the majority of the fission products along with the associated minor actinides. The recovered uranium metal undergoes successive heating steps to remove process media (electrorefiner salt) and is simultaneously down-blended through the addition of natural or depleted uranium to achieve a final U-235 enrichment of less than $20 \%$. During the heating process, the molten uranium is sampled via the production of a casting pin which is subsequently transferred to the Analytical Laboratory for analyses that provides the measured concentrations of some isotopes of interest (e.g., ${ }^{234} \mathrm{U},{ }^{235} \mathrm{U},{ }^{236} \mathrm{U}$, and ${ }^{238} \mathrm{U}$ ) thus characterizing the recovered uranium metal. This approach for characterization has been conducted on all of the nearly 4 metric tons of $<20 \% \mathrm{U}$ metal recovered to date and is anticipated to continue for the remaining EBR-II spent fuel identified for future treatment. While this method provides for an accurate assessment of the inventory on the basis of the analyzed isotopes, complete characterization has required development of a method to determine the concentration of the non-measured isotopes (e.g., $\left.{ }^{232} \mathrm{U}\right)$ as well. Based on the data accumulated from this inventory, a bounding approximation can be prepared that characterizes the HALEU material to be prepared from this inventory.

\section{Evaluation}


Rev. 05

Title: Isotopic Characterization of HALEU from EBR-II Driver Fuel Processing

TEV No.: 3537 Rev. No.: 0 Project No.: 31059 Date: $10 / 17 / 2018$

FCF utilizes a Mass Tracking System (MTG) that employs process models to estimate and track the mass and composition of process material moving through the facility [REF. 1]. Files representing the mass and composition of the incoming spent fuel were generated [REF. 2, 3, 4] from reactor burnup and isotope generation codes; the code employed for this purpose is ORIGEN, or Oak Ridge Isotope Generation [REF. 5], which is commonly used for such purposes. Because isotopes of an element possess the same chemical properties of that element, one can use the isotopic distributions from the MTG process models [REF. 6] along with the measured concentrations from sample analysis to determine the concentration of the non-measured nuclides. See Appendix A for an example of this calculated approach. The combination of isotopic values collected via sample analysis and those calculated from modeled values based on ORIGEN codes can be used to provide a representative approximation of the isotopic inventory of the HALEU to be produced from uranium metal recovered as a result of processing the irradiated EBR-II elements.

Appendix B provides a table containing average values for the four directly measured uranium isotopes ${ }^{234} \mathrm{U},{ }^{235} \mathrm{U}$, ${ }^{236} \mathrm{U}$, and ${ }^{238} \mathrm{U}$, as well as maximum values for the calculated isotopes ${ }^{232} \mathrm{U},{ }^{233} \mathrm{U}, \&{ }^{237} \mathrm{U}$ for HALEU material intended to be produced from the FCF uranium product. These uranium isotope compositions values are judged to be bounding for the existing FCF uranium metal inventory, as well as for any future uranium recovered from ongoing treatment activities due to the incorporation of planned process enhancements intended to produce uranium metal with fewer impurities. It is recommended that the calculated compositions of U-232, U-233, and U-237 be used along with measured compositions of other uranium isotopes for assessment of environmental impact from HALEU fuel fabrication from FCF HALEU feedstock. Because the contribution of small amounts of these isotopes will have negligible impact on calculations of environmental impact of HALEU fuel fabrication, it is judged that the calculated U-232-, U-233, and U-237 values are suitable for the purpose.

\section{Impurity and Isotopic Composition}

Chemical and isotopic compositions determined using analytical chemistry methods have been obtained from a selected set of six casting batches [REF. 7], comprising roughly $202 \mathrm{~kg}$ of uranium. The six casting batches were selected to be conservatively representative of the impurity contents of FCF uranium product prepared for use as HALEU feedstock. An effort is underway to identify a process of blending of prior FCF uranium product ingots with newly produced FCF uranium product to produce HALEU feedstock ingots with further reduced impurities and more consistent U-235 enrichment; i.e., a process to improve prior and forthcoming FCF uranium product to material suitable for use as HALEU feedstock in HALEU fuel fabrication in gloveboxes. Early results, yet incomplete, indicate that further developments in the process scheme have the potential to result in further decontamination than that achieved in those six casting batches. Therefore, the average of the measured and chemical isotopic analyses from those six batches (Appendix C) is judged to be representative and conservatively bound the impurity contents of future casting batches of HALEU feedstock to be used in HALEU fuel fabrication. Because the objective in that previous six-batch study was to assess decontamination potential, the content of nondetectable uranium isotopes (U-232, U-233, and U-237) was not calculated. However, the U-232, U-233, and U237 contents calculated for all prior casting batches, as described in the previous section, are the best-available estimate of contents in the HALEU feedstock going forward; the varying degrees of decontamination does not change the relative uranium isotopic composition.

\section{CONCLUSION / RECOMMENDATION}

The existing analytical reports in combination with the methodology used to calculate non-measured isotopes of interest provide an accurate and bounding estimate of the isotopic composition of the HALEU feedstock 
Rev. 05

Title: $\quad$ Isotopic Characterization of HALEU from EBR-II Driver Fuel Processing

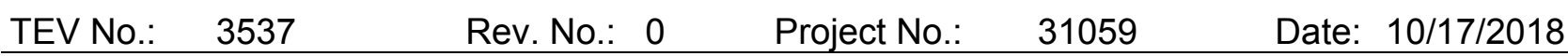

anticipated to be produced from the inventory of uranium metal recovered from the treatment of EBR-II fuel. This applies to both the existing inventory generated over the course of the past 25 years, as well as any future quantities to be generated as the result of ongoing treatment activities. The isotopic and impurity compositions as-measured in Appendix C, and supplemented with the calculated compositions for U-232, U-233, and U-237 as listed in Appendix B are recommended as a bounding composition (i.e., conservatively bounding uncertainties) for calculations of environmental impacts associated with HALEU fuel fabrication using HALEU feedstock from FCF.

\section{REFERENCES}

1. C. H. Adams, et. al., "The Mass Tracking System - Computerized Support for MC\&A and Operations at $F C F$ " Proceedings of the Embedded Topical Meeting on DOE Spent Nuclear Fuel \& Fissile Material Management, Reno, NV, June 1996, p. 369.

2. R. D. McKnight, "ANL Calculational Methodologies for Determining Spent Nuclear Fuel Source Term”, International Conference on the Physics of Nuclear Science and Technology, Long Island, NY (US), July 1998.

3. D. Vaden, "GENERATING ISOTOPE-Z (ISOZ) FILES FROM ORIGEN OUTPUT FAST FLUX TEST FACILITY FUEL ASSEMBLIES”, TEV-516, September 2010.

4. G. G. Galbreth, “GENERATING ISOTOPE-Z (ISOZ) FILES FOR MK-IA AND MK-II GENERATION FUEL ASSEMBLIES”, ECAR-1747, January 2012.

5. M. J. Bell, “ORIGEN - The ORNL Isotope Generation and Depletion Code," ORNL 4628, Oak Ridge National Laboratory (May 1973).

6. D. Vaden, "Fuel Conditioning Facility Electrorefiner Process Model”, Separation Science and Technology, Volume 41, Number 10, Pages: 1985 - 2001 (2006).

7. Idaho National Laboratory-Materials and Fuels Complex, Analytical Laboratory Final Reports, Log\#s 98739-98741, 100554-100556, 100215-100217, 100760-100762, 100975-100977, and 101079-101081. 
Rev. 05

Title:

TEV No.: $\quad 3537$

Rev. No.: 0

Project No.: $\quad 31059$

Date: $10 / 17 / 2018$

\section{Appendix A}

\section{Engineering Inputs}

Tables A-1 and A-2 provide results of measured and calculated uranium isotopic composition derived for a single furnace casting batch (batch CFBF18A), as an example of those similarly derived from all FCF uranium product batches.

In Table A-1:

- The second column contains the measured weight fractions of uranium isotopes for casting furnace batch CFBF18A.

- Note: the weight fractions of elemental and isotopic uranium are based on the entire sample, which is why the sum of the uranium isotopes is less than $100 \%$. Table A-2 performs the calculations for the isotopic fractions of uranium and does sum to $100 \%$.

- The third column contains the estimated weight fractions of uranium isotopes from the FCF MTG. The MTG process models, starting with the initial uranium isotopic distribution from ORIGEN calculations, estimated the isotopic distribution of uranium isotopes at the casting furnace.

- In the fourth column, the term "best available" means: if the measured weight fraction is available, use it; if not available, then use the estimated weight fraction. Note in the last row of the fourth column the best available weight fractions sum to a value not equal to the measured total uranium. The best available weight fractions are divided by their sum and multiplied by the measured uranium to produce the final uranium weight fractions shown in the fifth column.

Table A-1. Uranium Isotopic Distribution in Casting Furnace Batch CFBF18A (weight fraction)

\begin{tabular}{|c|c|c|c|c|}
\hline $\begin{array}{c}\text { Nuclide } \\
\mathbf{X}\end{array}$ & $\begin{array}{c}\text { Weight } \\
\text { Fraction } \\
\text { Measured }\end{array}$ & $\begin{array}{c}\text { Weight } \\
\text { Fraction } \\
\text { Estimated }\end{array}$ & $\begin{array}{c}\text { Weight } \\
\text { Fraction } \\
\text { Best Available }\end{array}$ & $\begin{array}{c}\text { Weight } \\
\text { Fraction } \\
\text { Final }\end{array}$ \\
\hline${ }^{232} \mathrm{U}$ & & $8.700 \mathrm{E}-10$ & $8.700 \mathrm{E}-10$ & $8.725 \mathrm{E}-10$ \\
\hline${ }^{233} \mathrm{U}$ & & $1.276 \mathrm{E}-07$ & $1.276 \mathrm{E}-07$ & $1.280 \mathrm{E}-07$ \\
\hline${ }^{234} \mathrm{U}$ & $2.104 \mathrm{E}-03$ & $2.102 \mathrm{E}-03$ & $2.104 \mathrm{E}-03$ & $2.110 \mathrm{E}-03$ \\
\hline${ }^{235} \mathrm{U}$ & $1.903 \mathrm{E}-01$ & $1.902 \mathrm{E}-01$ & $1.903 \mathrm{E}-01$ & $1.909 \mathrm{E}-01$ \\
\hline${ }^{236} \mathrm{U}$ & $6.314 \mathrm{E}-03$ & $6.310 \mathrm{E}-03$ & $6.314 \mathrm{E}-03$ & $6.333 \mathrm{E}-03$ \\
\hline${ }^{237} \mathrm{U}$ & & $1.158 \mathrm{E}-14$ & $1.158 \mathrm{E}-14$ & $1.161 \mathrm{E}-14$ \\
\hline${ }^{238} \mathrm{U}$ & $7.983 \mathrm{E}-01$ & $7.978 \mathrm{E}-01$ & $7.983 \mathrm{E}-01$ & $8.007 \mathrm{E}-01$ \\
\hline $\mathrm{U}$ & $9.970 \mathrm{E}-01$ & $9.970 \mathrm{E}+00$ & $9.970 \mathrm{E}-01+4.350 \mathrm{E}-05$ & $9.970 \mathrm{E}-01$ \\
\hline
\end{tabular}


Rev. 05

Title:

TEV No.: $\quad 3537$

Rev. No.: 0

Project No::

31059

Date: $10 / 17 / 2018$

In Table A-1:

- The second column contains the measured isotopic fractions of uranium isotopes for casting furnace batch CFBF18A.

- The third column contains the estimated isotopic fractions of uranium isotopes from the FCF MTG. The MTG process models, starting with the initial uranium isotopic distribution from ORIGEN calculations, estimated the isotopic fractions of uranium isotopes at the casting furnace.

- In the fourth column, the term "best available" means: if the measured isotopic fraction is available, use it; if not available, then use the estimated isotopic fraction. Note in the last row of the fourth column the best available isotopic fractions sum to a value greater than one. The best available isotopic fractions are divided by their sum to produce the final uranium isotopic fractions shown in the fifth column.

Table A-2. Uranium Isotopic Distribution in Casting Furnace Batch CFBF18A (isotopic fraction)

\begin{tabular}{|c|c|c|c|c|}
\hline $\begin{array}{c}\text { Nuclide } \\
\mathbf{X}\end{array}$ & $\begin{array}{c}\mathbf{g} \mathbf{X} / \mathbf{g ~ U} \\
\text { Measured }\end{array}$ & $\begin{array}{c}\mathbf{g} \mathbf{X} / \mathbf{g ~ U} \\
\text { Estimated }\end{array}$ & $\begin{array}{c}\mathbf{g} \mathbf{X} / \mathbf{g} \mathbf{U} \\
\text { Best Available }\end{array}$ & $\begin{array}{c}\mathbf{g} \mathbf{X} / \mathbf{g ~ U} \\
\text { Final }\end{array}$ \\
\hline${ }^{232} \mathrm{U}$ & & $8.927 \mathrm{E}-10$ & $8.927 \mathrm{E}-10$ & $8.926 \mathrm{E}-10$ \\
\hline${ }^{233} \mathrm{U}$ & & $1.310 \mathrm{E}-07$ & $1.310 \mathrm{E}-07$ & $1.310 \mathrm{E}-07$ \\
\hline${ }^{234} \mathrm{U}$ & $2.110 \mathrm{E}-03$ & $2.164 \mathrm{E}-03$ & $2.110 \mathrm{E}-03$ & $2.110 \mathrm{E}-03$ \\
\hline${ }^{235} \mathrm{U}$ & $1.909 \mathrm{E}-01$ & $1.959 \mathrm{E}-01$ & $1.909 \mathrm{E}-01$ & $1.909 \mathrm{E}-01$ \\
\hline${ }^{236} \mathrm{U}$ & $6.333 \mathrm{E}-03$ & $6.484 \mathrm{E}-03$ & $6.333 \mathrm{E}-03$ & $6.333 \mathrm{E}-03$ \\
\hline${ }^{237} \mathrm{U}$ & & $1.190 \mathrm{E}-14$ & $1.190 \mathrm{E}-14$ & $1.190 \mathrm{E}-14$ \\
\hline${ }^{238} \mathrm{U}$ & $8.007 \mathrm{E}-01$ & $7.954 \mathrm{E}-01$ & $8.007 \mathrm{E}-01$ & $8.007 \mathrm{E}-01$ \\
\hline Total & $1.000 \mathrm{E}+00$ & $1.000 \mathrm{E}+00$ & $1.000 \mathrm{E}+00+4.363 \mathrm{E}-05$ & $1.000 \mathrm{E}+00$ \\
\hline
\end{tabular}


TEM-10300-1

$12 / 19 / 2017$

TECHNICAL EVALUATION

Page B1 of B1

Rev. 05

Title:

TEV No.: $\quad 3537$

Rev. No.: 0

Project No.:

31059

Date: $10 / 17 / 2018$

\section{Appendix B}

\section{HALEU Assay}

\begin{tabular}{|c|c||c|c|c|}
\hline Analyte & Units & Average & Minimum & Maximum \\
\hline \hline Total U & wt. \% & 99.95 & 99.89 & 99.97 \\
U232^ & ppbU & 0.66 & 0.07 & 5.04 \\
U233^ $^{\wedge}$ & ppbU & 49.12 & 4.88 & 318.43 \\
U234* & iso \% U & 0.17 & 0.16 & 0.21 \\
U235* $^{*}$ & iso \% U & 19.39 & 18.97 & 19.99 \\
U236* & iso \% U & 0.58 & 0.50 & 1.22 \\
U237^ & pptU & 0.06 & 0.00 & 0.22 \\
U238* & iso \% U & 79.86 & 79.05 & 80.36 \\
\hline
\end{tabular}

$\wedge$ Isotope content beyond detection limits, so calculated using method described in Appendix A

* Actinide isotopes measured analytically $\mathrm{ppbU}=\mathrm{g}$ per billion grams of uranium iso. $\% U$ = isotope wt.\% of total $U$ $\mathrm{pptU}=\mathrm{g}$ per trillion grams of uranium 
TEM-10300-1

$12 / 19 / 2017$

TECHNICAL EVALUATION

Page C1 of C1

Rev. 05

Title:

TEV No.: $\quad 3537$

Rev. No.: 0

Project No::

31059

Date: $10 / 17 / 2018$

Appendix C

\section{Measured Chemical and Isotopic Composition of Six FCF Uranium Product Casting Batches $(202 \mathrm{~kg})$}

\begin{tabular}{|c|c|c|c|c|}
\hline Analyte & Units & $\begin{array}{l}\text { Weighted } \\
\text { Average }\end{array}$ & Minimum & Maximum \\
\hline Total U & wt. \% & 99.67 & 98.06 & 99.99 \\
\hline $\mathrm{Zr}$ & ppm & 101.45 & 59.80 & 146.50 \\
\hline $\mathrm{Si}$ & $\mathrm{ppm}$ & 77.60 & 40.00 & 130.00 \\
\hline$Y$ & $\mathrm{ppm}$ & 6.05 & 5.00 & 10.00 \\
\hline $\mathrm{Fe}$ & $\mathrm{ppm}$ & 133.13 & 39.90 & 574.00 \\
\hline $\mathrm{Cr}$ & ppm & 28.15 & 15.00 & 115.00 \\
\hline $\mathrm{Ni}$ & ppm & 43.14 & 30.00 & 68.80 \\
\hline Mo & ppm & 40.21 & 10.00 & 75.00 \\
\hline $\mathrm{Mn}$ & ppm & 79.47 & 13.80 & 190.00 \\
\hline $\mathrm{Ru}$ & $\mathrm{ppm}$ & 77.23 & 40.00 & 130.00 \\
\hline $\mathrm{Cd}$ & $\mathrm{ppm}$ & 12.17 & 5.00 & 20.00 \\
\hline $\mathrm{Al}$ & ppm & 101.24 & 20.00 & 285.00 \\
\hline Tc & ppm & 75.00 & 65.00 & 85.00 \\
\hline $\mathrm{Li}$ & $\mathrm{ppm}$ & 15.60 & 5.00 & 40.00 \\
\hline $\mathrm{K}$ & wt. \% & 0.05 & 0.01 & 0.15 \\
\hline $\mathrm{Na}$ & ppm & 82.29 & 35.00 & 200.00 \\
\hline $\mathrm{Ba}$ & $\mathrm{ppm}$ & 5.00 & 5.00 & 5.00 \\
\hline $\mathrm{Sr}$ & ppm & 5.00 & 5.00 & 5.00 \\
\hline Sr90 & $\mathrm{ppb}$ & 15.77 & 0.31 & 62.50 \\
\hline $\mathrm{Nd}$ & ppm & 95.92 & 25.00 & 200.00 \\
\hline $\mathrm{Sm}$ & ppm & 56.82 & 20.00 & 160.00 \\
\hline Tc99 & $\mathrm{ppm}$ & 0.15 & 0.06 & 0.28 \\
\hline
\end{tabular}

\begin{tabular}{|c|c|c|c|c|}
\hline Analyte & Units & $\begin{array}{c}\text { Weighted } \\
\text { Average }\end{array}$ & Minimum & Maximum \\
\hline Cs135 & ppm & 2.67 & 2.00 & 3.00 \\
\hline Mn54 & ppt & 3.04 & 0.04 & 12.52 \\
\hline Co60 & ppt & 27.81 & 0.27 & 176.99 \\
\hline Nb95 & ND & ND & ND & ND \\
\hline Zr95 & ND & ND & ND & ND \\
\hline Rh106 & ND & ND & ND & ND \\
\hline Ru106 & ND & ND & ND & ND \\
\hline Sb125 & ppt & 102.51 & 2.88 & 480.77 \\
\hline Cs134 & ppt & 24.99 & 0.23 & 153.85 \\
\hline Cs137 & ppb & 8.00 & 0.55 & 22.38 \\
\hline Ce144 & ppt & 67.11 & 1.88 & 313.48 \\
\hline Eu154 & ppb & 0.22 & 0.00 & 1.11 \\
\hline Eu155 & ppb & 0.22 & 0.00 & 1.04 \\
\hline Am241 & ppb & 61.23 & 2.92 & 291.55 \\
\hline U234 & iso. \%U & 0.16 & 0.16 & 0.18 \\
\hline U235 & iso. \%U & 19.28 & 18.92 & 19.42 \\
\hline U236 & iso. \%U & 0.52 & 0.49 & 0.56 \\
\hline U238 & iso. \%U & 79.76 & 79.03 & 80.03 \\
\hline Np237 & ppm & 17.11 & 13.90 & 21.40 \\
\hline Pu239 & ppm & 83.57 & 58.73 & 103.00 \\
\hline Pu240 & ppm & 2.24 & 1.46 & 2.71 \\
\hline Total Pu & ppm & NM & NM & NM \\
\hline
\end{tabular}

$\mathrm{ppm}=$ parts per million, by mass

$\mathrm{ppb}=$ parts per billion, by mass

$\mathrm{ppt}=$ parts per trillion, by mass

iso. $\% \mathrm{U}=$ isotope wt. $\%$ of total $\mathrm{U}$

$\mathrm{ND}=$ Not detected

$\mathrm{NM}=$ Not measured; total Pu was not measured. Np237, Pu239, and Pu240 isotopes are shown as ppm of material mass.

NOTE:

- The elemental impurities consist of isotopes in their natural isotopic abundance based on cooling time and the original source of the elements.

- Elemental $\mathrm{Sr}$ and $\mathrm{Ba}$ were below the minimum detection limit (MDL) of $5 \mathrm{ppm}$.

- Measurements below the MDL are listed at the MDL for conservatism. 